\title{
Book Review: The Holy Land in English Culture 1799-1917: Palestine and the Question of Orientalism By Eitan Bar-Yosef (Review) Oxford, 319 pp, October 2005, ISBN 0199261164
}

\author{
Fatin Abu Hilal \\ Department of English \\ Yarmouk University, Jordan
}

Received: 17-11-2014

Accepted: 20-12- 2014

Published: 01-01- 2015

doi:10.7575/aiac.ijclts.v.3n.1p.1

URL: http://dx.doi.org/10.7575/aiac.ijclts.v.3n.1p.1

Eitan Bar-Yosef selects "a memorable" image published in Punch in 1917 for the hard cover of his book, The Holy Land in English Culture: 1799-1917: Palestine and the Question of Orientalism, which captioned "The Last Crusade." It manifests a drawing of the historical Richard Coeur de Lion looking down from up a mountain towards a lower positioned Jerusalem with one hand on his sword, and the other on his armor. According to Punch it expresses 'My dream comes true!' (Punch, 153 (19 Dec., 1917), 415). In Bar-Yosef's words, this "epitomized the great achievement," (247) referring to the celebration of the historical surrendering of Jerusalem on 9 December 1917 by the British forces under the leadership of Edmund Allenby. This image restores the cultural and historical heritage of the Western Medieval Holy Wars into the British Modern existence. Though Bar-Yosef focuses on the"limited currency of the Crusading theme," (250), concerning its relevance to the construction of the Holy Land in English culture, he shows how this illustration depicts a widespread British phenomenon, what he calls the "Crusading mania," which appears in different textual forms in the Western culture. More specifically, he shows how the same idea is articulated in different expressions in the British media: "Khaki Crusaders" (1919), "Temporary Crusaders" (1919), "The Modern Crusaders" (1920), "The Last Crusade" (1920), "With Allenby's Crusaders" (1923), and so forth, without offering any "variation on the theme."

Bar-Yosef's book maintains that the image of the Holy Land in the British culture is "associated not with memories of medieval European conquest," what he calls "the Crusading image," nor with an "original" territorial Jerusalem in Palestine, but rather with "the traditions and institutions of vernacular biblical culture, from Sunday-school; hymns to the family bible" (250). This gives rise to what Bar-Yosef calls "vernacular Orientalism" which he defines as "the internalization of the Holy Land in English culture" (88). Specifically, his book explores the cultural processes of internalizing the scriptural Palestine (through the different devices of the vernacular biblical culture), then re-imagining it and (re)-producing it symbolically as "home" or England. Employing the vocabulary of a British biblical culture, Bar Yosef evokes a systematic metaphorical reflection of Jerusalem, one that produces the Holy City "self-reflexively" as England or 'home' in the British culture.

In revising Edward Said's foundational book, Orientalism (1978), Bar-Yosef considers that Said's model of Orientalism cannot accommodate the specificity of the Holy Land encounter in the English culture. He argues that "... Said very rarely stops to think about the distinct nature of Western interests in the Holy Land, which might distinguish it from other Orientalist encounters" (6). In order to maintain a distance from Said's theory, he suggests that the systematic "appropriations" of "biblical imagery" in the British cultural production is not connected with the real geography and history of the Holy Land (41), rather it is "firmly grounded in England soil (2) as "a symbol of social, denominational, and political contention" (2). It seems that Said's colonial discourse analysis theoy does not inclusively address this metaphorical aspect of Orientalist discourses. In keeping away from the discursive aspects of Orientalist encounters, he might not have had Said's colonial discourse analysis theory in his mind with its capacity to organize power relations inherent in the Western culture. However, while the representation of the Holy Land in the British culture articulates an unambiguous historical and imperialist desire and ideology concerning the (re)-possession of the Holy Jerusalem, BarYosef's insists on separating the representation of this image from its ideological, historical and religious backgrounds. In other words, whereas the "Crusading mania" (246) with which Bar-Yosef chooses to conclude his book, might discursively provide the cultural, geographical and historical contexts (or the idea of discourse, to borrow Said in this context) of the construction of the image of The Holy Land in English Culture, Bar-Yosef's analysis is based on a "metaphorical appropriation" (301) technique which keeps his analysis outside the specific historical and cultural contexts within which it works. In defying the complicated cultural perspective of the Holy Land "mania", Bar-Yosef creates a kind of spatial as well as cultural inaccessibility and remoteness in his analysis.

Being bounded in a metaphorical discourse, Bar-Yosef's analysis is delineated and confined outside the specific and actual cultural contexts within which it works. Even though he locates this functional allegory in different textual productions all throughout his book, his analysis keeps returning to The Bible, John Bunyan's masterpiece, The Pilgrim's Progress (1678) as well as the Blackean "Jerusalem in England" image with which he initiates his analysis, which are key texts in the "indoctrination" (38) of this metaphorical process. In chapter one, entitled: "Christian Walks to Jerusalem: English Protestant Culture and the Emergence of Vernacular Orientalism," Bar-Yosef insists on the metaphrical value of the Holy Land. He follows the Bunyanesque model which is based on a Biblical figurative style: 
'By metaphors I speak,'... [quoting Bunyan in his 'Apology']: 'was not Gods Laws,/ His Gospel-Laws in older time held fourth / By Types, Shadows and Metaphors?' (4). This is reflected in the metaphoric but not the literal reading of the geography and history of Palestine in the British culture. For example, he explains "The use of 'Zion' as a metonym for the city of Jerusalem or as a metaphor for the people of Israel is of course current in the Old Testament" (20). The shift from the literal to the metaphorical is sincerely carried out all throughout different types of texts in his book.

Even though the rest of the three chapters demonstrate how a growing body of systematic research and analysis of the geography and history of the Holy Land could complicate the Bunyanesque image that produces Jerusalem as a metaphoric image, Bar-Yosef maintains in his concluding chapter that "the metaphorical appropriations of the 'Holy Land' in the English cultural imagination always surpassed any actual weight that geographical Holy Land might have had in Britain's overall imperial design" (301). In this regard, in chapter two, entitled, The Land and the Book: High Anglo-Palestine Orientalism and its Limits, he scrutinizes the production of the Holy Land in cultural productions such as novels, travel writing and other forms of art and research producing what he calls the Academic Anglo-Palestine Orientalism. For example, he argues that before the establishment of the Palestine Association in London in 1805 and the historic PEF (Palestine Exploration Fund) which was sponsored by the British War Office in 1865, there was no systematic and programmed study or a "coherent body of texts"( 63) of the geography and natural history of biblical Palestine (72). It is relevant how the PEF signals the "gradual" and actual "penetration" (3) of the territorial Palestine. The fact that it was established to accomplish "cartographical" and "topographical" surveys of the land, and the fact that "clergymen work alongside military officials" in this project signified a historical and political "disturbing breakdown of boundaries," makes it necessary for Bar-Yosef to allow the literary as well as the non-literary to work across all cultural dimensions.

Furthermore, drawing on more diverse cultural forms, which extended from the 1830s to the First World War, chapter three, entitled, Popular Palestine: The Holy Land as Printed Image, Spectacle, and Commodity negotiates some of the major trends that became influential in "the academic Orientalist discourse" including the popular media, with emphasis on the Penny Magazine, Sunday-School Literature and curriculum, pictorial Bibles, models, exhibitions and dioramas - through which Victorians approached the Holy Land theme. This chapter traces the establishment of what John Davis calls the 'universal Holy Land visual literacy'(107). Bar-Yosef admits that such forms and trends "suggest" rather than "amplify" the reality of the Holy Land as a geographical space for exploration and conquest (179). He maintains that "rather than evoke the actual Palestine," the biblical Sunday-school culture deepens "the suppression of the real place" (180). He concludes that:

It was the Sunday school which stood at the heart of this biblical culture. With its scriptural geography classes and magic-lantern shows, the singing of hymns and the reading of Bible stories, the occasional visit to the model of Jerusalem or even to the Palestine Exhibition, the Sunday school introduced the Holy Land to its young pupils. Consequently, just like the school itself, the Holy Land became imbued with a powerful sense of nostalgia, a yearning towards tradition, communal identity, and family; Jerusalem, my happy home. (180)

Moreover, in considering the "affinity" among "diverse fields of" study including works by historians of empire, historical geographers, and literary writers, chapter four entitled: Eccentric Zion: Victorian Culture and the Jewish Restoration to Palestine considers the Victorian twentieth-century Zionist Christian historiography or Victiorian premillenarianism and the idea of Jewish restoration to Palestine. For example, following a Saidian technique, BarYosef shows how novels like Disraeli's Tancred and George Eliot's Daniel Derronda became central to "the Eastern Question debate" to the extent that "the Spectator famously complained in July 1878: 'For the last eight months at least, our policy has evidently been borrowed from Tancred' (Spectator, 13 July 1878, 883 in Bar-Yosef 217). In this respect, the Christian Zionist novels of the 1900s reflect the controversial position of Zionist tradition in the British culture. Among other works, these novels or what he calls "The Zionist plot in fiction" (232) show the growing conspicuousness and consciousness of the Zionist case and offer an account of the biblical "restoration narrative" (240), and in doing this, cannot be read apart, nor separated from an inherent religious ideology that has shaped the discourses of the Academic Anglo-Palestine Orientalism. Again it is unique how this strategic blending of the fictional, the religious, and the political in such narratives does not destabilize the central metaphoric mechanism through which Bar-Yosef's discourse proceeds in the text.

To sum up, the historical and religious density and intricacy in the Holy Land geography and culture should bring about changes in the homogeneous ways critics, historians, and archaeologists (even novelists) address the uniformity and evenness of the "scriptural aura" of the Palestinian Orientalist discourses. Since a "multilateral discourse," one that can incorporate the existence of Arabs and Islamic heritage, can destabilize the rigidness of the self-centered and one-sided scriptural history representation; any unilateral biblical/Zionist re-production of "the Land of the Bible" should cease to be tenable. This is indicative of the ubiquity of the idea of a cultural discourse and its ability to contain multiple components, both hegemonic and counter-hegemonic, that are enabled to acknowledge the historical specificity, complexity and multiplicity of the Palestinian cultural heritage (including the exceptionality, inimitability and distinctiveness of such discourses). However, in inserting Palestine in the cartography and title of his book, Bar-Yosef presents the complicated and dense position of the twentieth- century intellectual, especially when he invokes the idea that "the prospect of Jewish restoration was inviting both ethically and aesthetically" (246). Still, in not disturbing nor extending the rigid "boundaries" of his unilateral metaphoric discourse, such an analysis is reduced to a Westernized, long biblical typology of home and return, restoration and re-establishment that intends to "guide the wandering tribes back to a land of promise" (Graham 111) where a closure is always perfectly inscribed for the undying "Wandering Jew's Saga." 


\section{References}

Bar-Yosef, E. (2005). The Holy Land in English Culture 1799-1917: Palestine and the Question of Orientalism. Oxford: Oxford University Press

Bunyan, J. (1984). The Pilgrim's Progress. Ed. N. H. Keeble, World's Classics. Oxford: Oxford University Press

Davis, J. (1996). The Landscape of Belief: Encountering the Holy Land in Nineteenth-Century American Art and Culture. Princeton: Princeton University Press

Graham, W. (1902). The Zionists. London: Hutchinson

Said, E. (1978). Orientalism. Harmondworth, London: Penguin 